\title{
HUKUM ISLAM DAN PRANATA SOSIAL
}

\section{(Sebuah Kajian Makna Teks Nash)}

Oleh: Naskur

\begin{abstract}
ABSTRAK
Risalah Islam ternukil untuk mengkonsepsionalisasi kehidupan sosial manusia. Ini sebuah keyakinan dari umat Islam (baca: mukmin) dan dengan keyakinan ini Umat Islam selalu confidence untuk menata kehidupan sosial bersama yang dijalaninya secara sunnatullah dan berperadaban. Risalah Islam dengan dua sumbernya, Al-Quran dan Al-Hadis telah meletakan kerangka konstruksi dan konfigurasi sejumlah penata sosial sesuai hajat manusia dalam kehidupannya secara kolektif. Tulisan ini akan membedah hukum Islam dengan beberapa dimensi normatifnya dan dengan berbagai pranata sosial yang dikonsepnya.
\end{abstract}

Kata kunci: Islam, dimensi dan pranata sosial. 


\section{PENDAHULUAN}

Hukum Islam dan pranata sosial mengandung arti normatif dalam penataan kehidupan bermasyarakat yang berpangkal dan penerimaan terhadap sumber ajaran Islam. Hukum deduksi dari pra penataan untuk memenuhi kebutuhan hidup manusia dalam suatu komunitas. Kedua hal tersebut di atas menjadi unsur penata tentang berbagai bidang kehidupan dari suatu sistem sosial yang bersifat otonom.

Dalam penduduknya sebagai unsur normatif dalam penataan kehidupan hukum, dalam bentuk dan jenis apa pun berkenaan dengan pengaturan dan kekuasaan. Sedangkan kekuasaan dapat diartikan sebagai kemampuan mempengaruhi atau mengarahkan kepada manusia untuk melakukan atau meninggalkan perbuatan sesuai dengan kehendak perintah atau larangan yang berkuasa. Kekuasaan melekat pada Tuhan, melekat pada manusia dan melekat pada organ dalam organisasi masyarakat yakni negara.

Dari pengertian kekuasaan tersebut di atas memberikan petunjuk bahwa kekuasaan itu bervariasi baik graduasinya maupun kekuasaanya. Oleh karena itu, daya ikat dan daya paksa hukum dalam penataan kehidupan manusia tergantung pada graduasi kekuasaan yang memproduknya. Ada hukum yang memiliki daya ikat yang longgar dan ada pula yang memiliki daya ikat yang ketat. Di samping itu ada yang memiliki daya pasa meskipun dalam dalam batas-batas tertentu.

Hukum Islam merupakan rangkaian kata "Hukum" dan kata "Islam". Kedua kata itu, secara terpisah, merupakan kata yang digunakan dalam bahasa Arab dan terdapat dalam Al-Quran, juga berlaku dalam bahasa Indonesia. Untuk memahami hukum Islam, perlu diketahui lebih dahulu kata "hukum" dalam bahasa Indonesia, kemudian disandarkan kepada kata "Islam". Pengertian hukum secara sederhana yaitu: "Seperangkat peraturan tentang tingkah laku manusia yang diakui sekelompok masyarakat; disusun orang-orang yang diberi wewenang oleh masyarakat itu; berlaku dan mengikat untuk seluruh anggotanya". Bila "pengertian hukum" tersebut dihubungkan kepada "Islam" atau "Syara", maka "Hukum Islam" akan berarti: Seperangkat peraturan berdasarkan wahyu Allah dan Sunnah Rasul Jurnal Al-Syir’ah Vol. 1 No. 2 Juli-Desember 2003 
tentang tingkah laku manusia mukhallaf yang diakui dan diyakini mengikat untuk semua yang beragama Islam”.

Berdasarkan pengertian "hukum Islam" tersebut dapat ditarik suatu kesimpulan bahwa "hukum Islam" adalah peraturan tentang tingkah laku manusia didasarkan pada Wahyu Allah dan Sunnah Rasul. Dari uraian-uraian di atas dalam pembahasan hukum Islam dan pranata sosial penulis mengangkat suatu permasalahan "Bagaimana hukum Islam dengan pranata sosial.

\section{DIMENSI HUKUM ISLAM}

Berkenaan dengan pembahasan hukum Islam dan pranata sosial, ada beberapa dimensi-simensi hukum Islam yang perlu diketahui sebagai berikut:

a. Dimensi Syariah

Dengan prinsip dan fungsi itu, sumber hukum (mashadir al-ahkam atau aladillah al-Syariah) adalah ayat-ayat Al-Quran mencakup akidah dan ayatayat hukum kemudian diimplementasikan dalam sunnah atau hadis, hukum Islam dideduksi dari kedua sumber sumber tersebut dengan asumsi bahwa Allah swt. Dan RasulNya memiliki kekuasaan untuk mengatur kehidupan manusia dalam berbagai aspeknya (musyari) yang menjadi sumber dalam pembentukan dan pengembangan hukum Islam dan menjadi patokan dalam mengarahkan dan memberi makna terhadap pelbagai pranata sosial. Sumber hukum Islam bersifat universal dan abadi. Ia memiliki daya atur dan daya ikat terhadap orang-orang beriman.

b. Dimensi Ilmu

Berkenaan dengan hal tersebut dikenal hukum Islam dalam dimensi pengetahuan ilmiah (al-ilm). Asumsi yang digunakan, bahwa ulama memiliki kekuasaan dalam bidang pengetahuan ilmiah. Oleh karena dimensi hubungan Islam sangat lentur. Maka daya ikatnya dan atur pun sangat lentur. Hukum Islam dalam dimensi pengetehuan ilmiah memiliki unsur-unsur substansi, informasi dan metodologi sebagai keilmuan yang bersifat universal dan otonom, tanpa terikat oleh sistem sosial maupun. Ia 
seolah-olah anti struktur dan hanya menjadi konvensi dikalangan komunitas ilmiah.

c. Dimensi Fiqh

Dimensi ini merupakan produk penalaran fuqaha yang dideduksi dari sumber Al-Quran dan teks Hadis yang otentik, lalu didokumentasikan dalam Kitab Fiqh yang tersusun secara sistemik dan mencakup berbagai bidang kehidupan, mulai dari thahara sampai jihad. Ia dapat diidentifikasikan sebagai hukum.

d. Dimensi Hukum Islam

Dimensi ini merupakan suatu kompleks hukum Islam yang tumbuh dan berkembang di dalam kehidupan masyarakat yang dapat dijadikan bahan baku dalam penysuanan peraturan perundang-undangan. Terbentuknya dan berfungsinya sistem hukum nasional yang mantap, bersumberkan pancasila dan UUD 1945 dengan memperhatikan, kemajemukan tatanan hukum yang berlaku, yang mampu menjamin kepastian, ketertiban, penegakan serta mampu mengamankan dan mendukung pembangunan nasional.

e. Dimensi Qadha

Dimensi adalah merupakan produk pengadilan yang terdiri dari atas putusan (al-qadha) dan penetapan (al-itsbat), baik pengadilan dalam lingkungan agama maupun terhadap perkara yang diajukan, mengacu kepada hukum tertulis dan hukum tidak tertulis.

f. Dimensi Adat

Dimensi ini adalah perilaku yang mempola (al'adah). Dimensi tersebut merupakan hukum yang hidup di dalam masyarakat yang terjadi melalui proses internalisasi dalam interaksi sosial, khususnya dalam bidang hukm keluarga. Hukum tersebut dilakukan tanpa interaksi kekuasaan negara atau kekuasaan tradisional dan kharismatik, tetapi dilakukan atas dasar kesukaralaan (al-ridha), sebab masyarakat bangsa Indonesia itu majemuk (pluralistik). Baik secara horisontal maupun secara vertikal. Maka corak adat itu bersifat majemuk pula. Dimensi adat ini sangat bervariasi dan merupakan kekayaan nuansa bangsa Indonesia. 
Dalam dimensi hukum di atas yeng penulis paparkan, maka dapatlah dikatakan bahwa tujuan hukum Islam adalah untuk tercapainya maslahat. Dalam kajian hukum Islam, konsep maslahat dipahami sebagai metode yang dipergunakan saat melakukan istinbat (menetapkan hukum berdasarkan dalildalil yang terdapat pada nash). Para yuridis Islam (ahli ushul fiqh) membagi maslahat kepada tiga macam.

1. Al-mashlahah adl-dlarusiyah, yaitu kemaslahatan yang berhubungan dengan kebutuhan pokok umat manusia di dunia dan di akhirat. Yang termasuk dalam kemaslahatan ini adalah memelihara agama, memelihara akal, memelihara keturunan, memelihara jiwa dan memlihara harta.

2. Al-mashlahah al-hajiyah, yaitu kemaslahatan yang dibutuhkan dalam menyempurnakan kemaslahatan yang mendukung kemaslahatan hajiyat. Jika seorang hendak memelihara jiwa, maka para penegak hukum mutlak dipergunakan, hal tersebut guna menciptakan kemaslahatan dalam menjaga jiwa dan harta. Dengan demikian, kemaslahatan ini menjaga kemaslahatan yang pertama.

3. Al-mashlahah al-tahsimiyyah, yaitu kemaslahatan yang sifatnya pelengkap berupa keleluasaan yang dapat melengkapi kemaslahatan pertama. Jika kita ingin memelihara jiwa, maka kebutuhan akan dokter jiwa merupakan suatu yang diperlikan jika tidak dikatakan suatu yang mutlak pada setiap daerah.

\section{HUKUM ISLAM DAN PRANATA SOSIAL}

Sebagaimana dikemukakan di atas, hukum Islam mencakup dimensi yang bervariasi, ia mengalami internalisasi ke dalam berbagai pranata sosial yang tersedia di dalam masyarakat. Pranata sosial didapat dari dua sudut pandang.

1. Pranata sosial merupakan aktualisasi hukum Islam yang bertumpu pada interaksi sosial yang berpola setelah mengalami pergumulan dengan kaidah-kaidah lokal yang dianut oleh masyarakat Indonesia yang majemuk. Dalam pergumulan terjadi adaptasi dan kodifikasi antara hukum Islam dengan kaidah lokal atau dengan perkataan lain. 
Proses sosialisasi dan institusionalisasi hukum Islam terjadi dalam hubungan timbal balik dengan kaidah-kaidah lokal yang dianut.

2. Pranata-pranata itu merupakan perwujudan interaksi sosial dalam masyarakat untuk memenuhi kebutuhan hidup mereka. Interaksi sosial itu berpatokan dan mengacu kepada keyakinan nilai dan kaidah yang dianut oelh mereka. Ia merupakan perwujudan amal salehsebagai ekspresi ke imanan dalam interaksi sosial.

Pranata sosial itu muncul dan berkembang sebagai refleksi dari sebuah kebudayaan manusia yang menurut Kluckhom adalah keseluruhan cara hidup manusia. Hal yang senada dikemukakan oleh Yusran bahwa pranata sosial erat hubungannya dengan kebudayaan manusia sebab pranata itu sebdiriberarti sistem tingkah laku sosial yang bersifat resmi berupa adat istiadat dan norma yang mangetur tingkah laku serta seluruh perlengkapannya guna berbagai kompleks manusia di dalam masyarakat. Dengan demikian, secara umum penulis dapat merumuskan bahwa pranata sosial adalah tradisi-tradisi dalam kehidupan manusia yang terbentuk sebagai kombinasi antara reaksi kemanusiaan atas tantangan dan dinamika lingkungannya, dengan etos yang menjadi nilai dasar kehidupan bagi umat Islam, dan nilai etos tersebut terbentuk dari ajaran-ajaran dasar yang dikembangkan oleh Al-Quran dan Sunnah.

Dalam kehidupan masyarakat Islam Indonesia dewasa ini, khususnya dikenal sebagai pranata sosial yang bercorak keislaman. Pranata-pranata itu meliputi berbagai bidang kehidupan yang senantiasa mengalami perkembangan dari waktu ke waktu. Ada pranata yang amat dekat dengan keyakinan yang dianut, sehingga memiliki tingkat kepekaan yang sangat tinggi, misalnya pranata peribadatan, pranata kekerabatan dan pranata pendidikan. (pembahasan tentang pranata ini akan dibahas pada ruang lingkup pranata) ada pula yang relatif agak jauh dari keyakinan, sehingga relatif luwes atau "netral" seperti pranata ekonomi. Selanjutnya, pranata itu mengalami kongkretisasi dalam struktur masyarakat dalam bentuk berbagai organisasi sosial sebagai wahana untuk memenuhi kebutuhan hidup secara kolektif dan terncana. Kenyataan itu menunjukkan bahwa di dalam masyarakat itu terjadi penyerapan produk teknologi sosial 
(pengorganisasi masyarakat) mutakhir dan dapat dijadikan saluran untuk mengaktualisasikan hukum Islam di dalam kehidupan nyata.

Menurut Dede bahwa dalam konteks kehidupan manusia pranata sosial memilki ruang lingkup:

1. Bidang Politik dan Pemerintahan

Misi Rasul untuk membawa bangsa Arab ke jalan kebenaran langsung berhadapan dengan kendala-kendala politik. Kepala-kepala Kabilah yang melakukan konfederasi dalam memimpin masyarakatnya, secara keseluruhan menentang dakwa Nabi, sehingga pada akhirnya dakwa Nabi pindah ke Madinah dan berhasil mempersatukan Muhajirin, Anshar, Kharaj dan Aus. Lalu kemudian Nabi tidak juga memimpin politik yang punya peran sebagai kepala negara di Madinah.

2. Bidang Peradilan

Bidang ini merupakan bagian penting dari misi Kerasulan Muhammad. Untuk itu, dismping menetapkan noma-norma hukum, Rasulullah juga melakukan proses pengadilan serta eksekusi hukuman dan memberikan ketentua-ketentuan acaranya.

3. Bidang Pertahanan dan Keamanan

Fungsi dalam bidang ini secara umum mencakup dua hal, yaitu bidang pertahanan dan keamanan negara dari berbagai tindak kejahatan, serta pelanggan terhadap norma-norma hukum. Sedangkan bidang pertahanan yang bertugas menjaga kemungkinan dari ancaman luar terhadap eksistensi negara.

4. Bidang Ekonomi dan Keuangan

Sumber perekonomian rakyat terdiri dari sektor-sektor jasa, industri, kerajinan dan pertanian. Bidang seni dan perdagangan. Sementara sumber keuangan negara adalah pajak, zakat, jizyah serta bea cukai.

5. Bidang Kesehatan

Pengetahuan dalam bidang kesehatan mengalami kemajuan yang cukuo besar. Dengan penerjemahan literatur-literatur Yunani, membuat cendekiawan Timur kontak dengan berbagai ilmu pengetahuan termasuk ilmu-ilmu tentang kesehatan, kimia dan obat- 
obatan, sehingga lahir dokter-dokter baru yang mapu melakukan diagnosa berbagai penyakit dan menemkan jenis-jenis obat tertentu.

Sementara itu Cik Hasan membagi ruang lingkup pranata yaitu:

1. Pranata Peribadatan

Pranata ini berfungsi sebagai pemenuhan kebutuhan manusia, sebagai hamba dalam melakukan hubungan dengan Allah swt. untuk memenuhi kebutuhan itu dilakukan penataan yang meliputi persyaratan, komponen (rukun) dan Kaifiahnya.

2. Pranata Kekerabatan

Pranata ini berfungsi sebagai pemenuhan kebutuhan pemeliharaan dan pengembangan keturunan dan juga untuk memelihara mengembangkan kebudayaan yang dianut secara kolektif. Pranata ini mengalokasikan nilai dan kaidah al-ahwal al-syakhshiyah yang berkenaan dengan perkawinan, pelamaran, perceraian, pendidikan anak dan kewarisan.

3. Pranata Pendidikan

Pranata ini berfungsi sebagai pemenuhan kebutuhan dalam mensosialisasikan keyakian, nilai-nilai dan kidah-kaidah yang dianut oleh suatu generasi berikutnya. Selanjutnya, sosialisasi itu meliputi informasi-informasi baru dan berbagai jenis keterampilan yang dibutuhkan di dalam kehidupan masyarakat.

4. Pranata Keilmuan

Pranata ini berfungsi sebagai pemenuhan kebutuhan dalam mengembangkan pemahaman terhadap ayat-ayat Allah swt. yaitu ayatayat qauliyah dn ayat-ayat kauniyah.

5. Pranata Penyiaran

Pranata ini berfungsi sebagai pemenuhan kebutuhan dalam penyebarluasan ajaran Islam di dalam masyarakat yang kemudian dikenal sebagai pranata dakwah.

6. Pranata Politik

Pranata ini berfungsi sebagai pemenuhan kebutuhan dalam mengalokasikan nilai-nilai fan kaidah-kaidah Islam melalui artikulasi di dalam kehidupan bermasyarakat berbangsa dan bernegara. 


\section{Pranatah Hukum}

Pranata ini berfungsi sebagai pemenuhan kebutuhan ketertiban dan ketentraman dalam kehidupan masyarkat. Untuk memenuhi kebutuhan itu dilakukan penataan kehidupan bersama yang disepakati yaitu hukum.

\section{Pranata Ekonomi}

Pranata ini berfungsi sebagai pemenuhan kebutuhan barang dan jasa di dalam keidupan masyarakat. Untuk memenuhi kebutuhan itu dilakukan berbagai akad dalam pola-pola produksi, distribusi dan konsumsi pendekatan keilmuan.

\section{Pranata Kesehatan}

Pranata ini berfungsi sebagai pemenuhan kebutuhan kreasi dan ekspresi kesenian. Hal itu merupakan bentuk ekspresi nilai-nilai keislaman dalam bentuk seni membaca Al-Quran, seni lukis, seni sastra, seni kaligrafi dan seni arsitektur.

\section{Pranata Perawatan Sosial}

Pranata ini berfungsi sebagai pemenuhan kebutuhan perawatan sosial bagi kelompok masyarakat tertentun karena keterbatasan sumber daya, memerlukan pelayanan dan perawatan dari kelompok masyarakat lainnya.

11. Pranata Kesenian

Pranata ini berfungsi sebagai pemenuhan kebutuhan kreasi dan ekspresi kesenian. Hal itu merupakan bentuk ekspresi nilai-nilai keislaman dalam bentuk seni membaca Al-Quran, seni lukis, seni sastra, seni kaligrafi dan seni arsitektur.

\section{KESIMPULAN}

Hukum Islam di Indonesia kaya sengan dengan dimensi dan substansi. Ia berdimensi abstrak dalam wujud segala perintah dan larangan Allah dan RasulNya. Ia juga berdimensi kongkrit dalam wujud perilaku yang mempola dikalangan umat Islam. Huku Islam juaga kaya dengan substansi yang terinternalisasi dan terinstitusionalisasi dalam berbagai pranata sosial dalam kehidupan masyarakat Islam dan masyarakat bangsa Indonesia. Dimensi dan substansi hukum Islam itu dapat dikatakan dan disebut sebagai hukum Islam dan pranata sosial Indonesia. 
Perkembangan hukum Islam melalui kegiatan pengkajian, pengajaran dan penerapannya di pengadilan merupakan upaya strategis untuk mengembangkan salah satu dari bagian ajaran Islam dalam kehidupan bermasyarakat dan bergama.

Tentu saja, perkembangan kawasan pengkajian itu tidak secara otomatis sebagai usaha dalam pengembangan itu. Sebab pengembangan ilmu apapun mencakup unsur lainnya. 